\title{
COVID-19 integrated imaging: our experience and literature review
}

\author{
Piero Trovato ${ }^{1, B, C, E}$, Igino Simonetti ${ }^{2, C, E, F}$, Chiara Rinald $0^{3, A, D}$, Dario Grimaldi ${ }^{1, B, D, E}$, Francesco Verde ${ }^{2, C, E}$, \\ Pascal Lomoro ${ }^{4, D}$, Umberto Codella ${ }^{1, B}$, Ferdinando De Rosa ${ }^{1, B}$, Antonio Corvino $0^{5,6, E}$, Sabrina Giovine ${ }^{1, B, D}$ \\ 'Department of Radiology, SG Moscati Hospital, ASL Caserta, Aversa, Italy \\ ¿University of Naples Federico II, Department of Advanced Biomedical Sciences, Italy \\ ${ }^{3}$ Radiology Department, Marcianise Hospital, ASL Caserta, Marcianise (CE), Italy \\ ${ }^{4}$ Radiology Department, Valduce Hospital, Como, Italy \\ ${ }^{5}$ Motor Science and Wellness Department, University of Naples "Parthenope", Naples, Italy \\ ${ }^{6}$ National Institute for Insurance against Accidents at Work (INAIL), Campania, Italy
}

\section{Abstract}

Purpose: To investigate the imaging features of emerging COVID-19 pneumonia on chest ultrasound, radiographs and computed tomography examinations performed at admission. In addition, we provide a review of the literature and compare our results with recent evidence regarding the imaging characteristics of this novel disease.

Material and methods: From March 17, 2020 to April 25, 2020, 23 patients with real-time polymerase chain reaction (RT-PCR) assay confirmed COVID-19 were identified. All 23 patients were evaluated and admitted at San Giuseppe Moscati Hospital in Aversa, Italy. Multi-modality imaging findings were evaluated and compared. Literature research was conducted through a methodical search on PubMed.

Results: Twenty-three patients were included in the study. Chest transthoracic ultrasound (US), chest X-ray (CXR), and computed tomography (CT) were performed respectively in 11, 16 and 21 patients. Chest US findings were consistent with diffuse B lines (91\%), subpleural consolidations (45\%), and thickened pleural line (18\%). CXR showed prevalent manifestations of consolidations (50\%) and hazy increased opacities (37\%). Typical CT features are bilateral and multilobar ground-glass opacities (GGO). Indeed GGO were present in $100 \%$ of our patients. Consolidations were visible in $76 \%$ of our study population. Notably both GGO and consolidations had a peripheral distribution in all our patients. Other CT imaging features included crazy-paving pattern, fibrous stripes, subpleural lines, architectural distortion, air bronchogram sign, vascular thickening and nodules. Our literature review identified thirty original studies supporting our imaging chest findings.

Conclusions: At admission, COVID-19 pneumonia can manifest in chest imaging as B-lines and consolidations on US, hazy opacities and consolidations on CXR, multiple GGO and consolidations on CT scan.

Key words: pneumonia, computed tomography (CT), COVID-19, SARS-CoV-2, coronavirus disease, radiographic chest examination (CXR).

\section{Introduction}

A new coronavirus, severe acute respiratory syndrome coronavirus 2 (SARS-CoV-2), was first reported from Wuhan, China, in December 2019, and then quickly spread to other countries around the world [1]. It is an enveloped RNA virus responsible for SARS-CoV-2 disease, denominated COVID-19. Clinical expression of the disease ranges from asymptomatic to a severe life-threatening course [2]. The dominant clinical presentation is characterized by high temperature and cough [3]. Up to $5.0 \%$ of the patients were admitted to intensive care units, $2.3 \%$ of them

Correspondence address:

Dr. Dario Grimaldi, Department of Radiology, SG Moscati Hospital, ASL Caserta, Aversa, Italy, e-mail: dariogrimaldi@me.com

Authors' contribution:

A Study design · B Data collection · C Statistical analysis · D Data interpretation · E Manuscript preparation · F Literature search · G Funds collection 
underwent invasive mechanical ventilation, and $1.4 \%$ of the patients died [1]. At present, real-time polymerase chain reaction testing (RT-PCR) for SARS-CoV-2 is the standard for diagnostic confirmation [4]. Imaging plays an important role in the diagnosis: ultrasound (US) and chest radiography (CXR) are offered as the first step; computed tomography (CT) is reserved for more severe cases or cases of discrepancy between clinical and radiographic findings, especially in the early stage where a swab test may be negative [5]. Our study aimed to systematically evaluate and compare the imaging findings of COVID-19 detected in 23 patients admitted to our hospital who underwent CXR, lung US and chest CT examinations. In addition, we have provided a complete overview of the literature to compare our results with recent evidence regarding the imaging features of this novel disease.

\section{Material and methods}

\section{Patients}

Our retrospective study was approved by the local institutional review board. From March 17, 2020, to April 25, 2020, a total of twenty-three patients ( 13 men, 10 women; age range, 53 to 84 years; mean age 72.7 years) with COVID-19 confirmed by RT-PCR assay and hospitalized in San Giuseppe Moscati Hospital (Aversa, Italy), were included. All patients underwent a chest radiological evaluation upon admission to our Emergency Department using chest CT and/or CXR and/or lung US. Clinical and laboratory data were also evaluated.

\section{Image acquisition}

Bedside lung US was performed in the Emergency Department using low frequency (2-5 MHz) convex probe and high frequency (5-10 MHz) linear probe. CXR was performed in the posteroanterior projection at full inspiration or in the anteroposterior projection in the supine patients. Chest CT examination was performed using a multi-detector CT scanner with 16 channels located in the emergency room and used exclusively for COVID-19 patients. The following were used as CT acquisition parameters: tube voltage of $120 \mathrm{kVp}$; tube current, standard (reference mAs, 60-120); slice thickness, $1.0 \mathrm{~mm}$; reconstruction interval of $1.0 \mathrm{~mm}$. The acquisition of all CT images was performed during full inspiration with the patient in full inspiration and without IV contrast medium.

\section{Image analysis}

All lung US, CXR, and CT images were reassessed by two expert thoracic radiologists in consensus (S.G. and F.D. with 27 and 14 years of experience in thoracic radiology). The following lung US findings were investigated: A-lines, B-lines, thickened pleural line, pleural consoli- dation, and effusion. CXR and CT features were classified according to the Fleischner Society Glossary [6]. The following chest radiographic findings were evaluated: hazy increased lung opacity, consolidation, and pleural effusion. CT images were analyzed in the pulmonary window, with a width of 1500 Hounsfield units (HU) and a level of $-600 \mathrm{HU}$, and in the mediastinal window, using a width of $350 \mathrm{HU}$ and a level of $50 \mathrm{HU}$. The following CT findings were assessed: distribution (peripheral, central or both), involved lung lobes (right upper lobe, middle lobe, lower lobe, left upper lobe, lower lobe), number of lobes involved (one, two, three, four, five), appearance (ground-glass opacity, consolidation, ground-glass opacity with consolidation), specific signs (air bronchogram sign, "crazy-paving" pattern, architectural distortion, fibrous stripes, subpleural lines, vascular thickening, and nodules), and extra-pulmonary alterations (pleural effusion and mediastinal enlarged lymph nodes).

\section{Results}

\section{Patient population and imaging examinations}

All twenty-three patients presented with clinical manifestations upon admission, including fever in twenty-three patients $(100 \%)$, cough in eleven patients (48\%), dyspnea in ten patients (43\%), and fatigue in thirteen patients (56\%). Laboratory tests showed low levels of lymphocytes in twenty patients (87\%) and high C-reactive protein levels in twenty-two patients (91\%). Available imaging examinations performed for each patient were as follows: CXR alone from six patients, CT alone from seven patients, while a combination of lung US and chest X-ray in two patients, lung US and chest CT in six patients, chest $\mathrm{X}$-ray and CT in five patients and lung US, chest X-ray and CT in three patients.

\section{US features}

Bedside lung US was performed in eleven patients. In ten cases (91\%), US showed various B-line patterns (focal, multifocal, confluent) with bilateral distribution, which indicated filling of intralobular or interlobular septa or opacities that did not obscure the underlying bronchial and lung structures. In five patients (45\%) a subpleural consolidation was observed while in two cases (18\%) US showed a thickened pleural line. In one case (9\%), a mixed pattern was highlighted with A- and B-lines. Moreover, in one patient $(9 \%)$, pleural effusion was also observed. Of these patients, chest X-ray was performed in five patients while chest CT was performed in nine patients; bilateral consolidations or hazy increased opacities were observed in chest X-ray examination (Figure 1) while bilateral ground-glass opacities (GGO) with consolidations were highlighted at CT evaluation (Figures 2 and 3). Detailed lung US findings are reported in Table 1. 

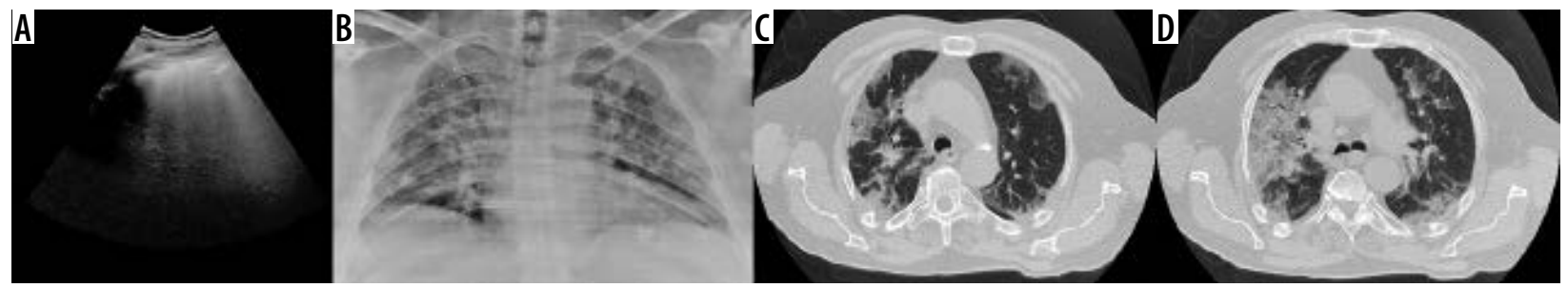

Figure 1. A) Lung ultrasound with convex probe shows irregular pleural surface and multiple B lines. B) Chest X-ray shows bilateral, central and peripheral, lung opacities. C, D) Axial chest computed tomography images show patchy bilateral ground-glass opacities with interlobular septal and intralobular interstitial thickening ("crazy-paving" pattern) in the upper lobes, mainly peripheral and more consolidated areas

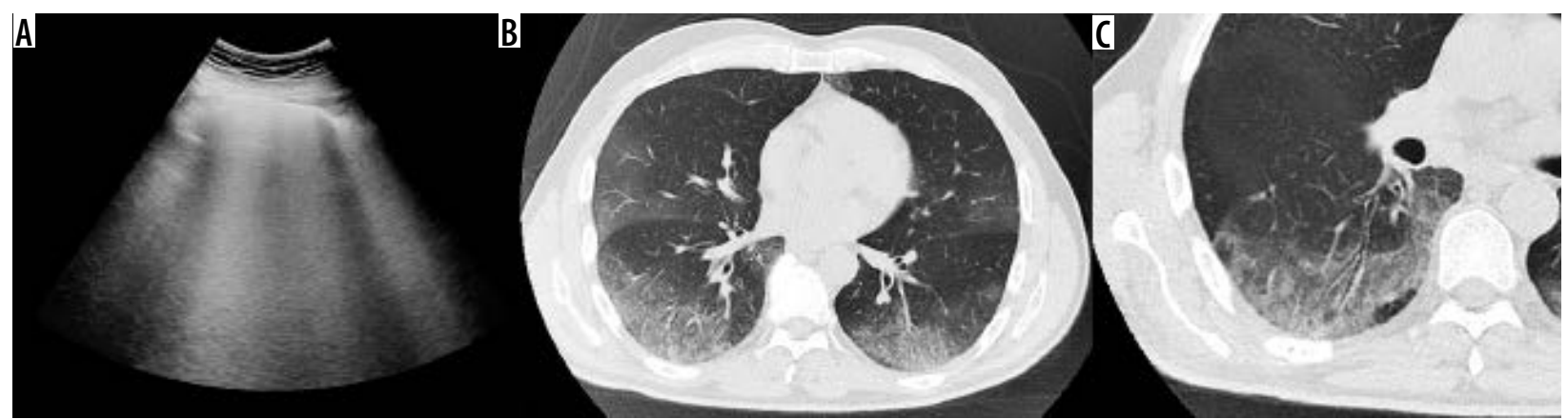

Figure 2. A) Lung ultrasound shows pleural line irregularities and confluent vertical artifacts (B-lines). B, C) Chest computed tomography axial images show bilateral and peripheral ground-glass opacities with "crazy-paving" pattern and air bronchogram sign in the lower lobes

\section{Chest X-ray findings}

CXR was performed in a total of sixteen patients. Of these, two patients (12\%) showed no abnormalities, although chest CT performed on the same day allowed bilateral GGO to be identified. In the remaining cases, eight patients (50\%) showed a consolidation while in six patients (37\%) a hazy increased opacity was identified; no pleural effusion was detected. The distribution of these features was bilateral in thirteen cases (81\%) and unilateral in one patient (6\%). Moreover, the lower lobes were involved in eight patients (50\%), while similar lower and upper zone involvement was observed in six cases (37\%) and upper zone involvement in only one patient (6\%). Among these patients, CT was performed on the same day in eight patients, showing correlated characteristics, especially bilateral GGO with consolidations predominantly involving the lower lobes (Figure 1). Detailed results of CXR findings are shown in Table 2.

\section{CT findings}

Twenty-one patients underwent a chest CT examination, which showed abnormalities in all cases. The most common CT findings were GGO (Figure 4), detected in 21 cases (100\%); among them, 16 (76\%) also showed concomitant consolidations (Figure 5). In all patients the lesions involved both lungs, generally 5 lobes (76\%), in particular, the right lower lobe (100\%) and the left lower lobe $(100 \%)$, with a prevalent peripheral distribution in twenty-one cases (100\%) while both peripheral and central localization was detected in sixteen patients (76\%).

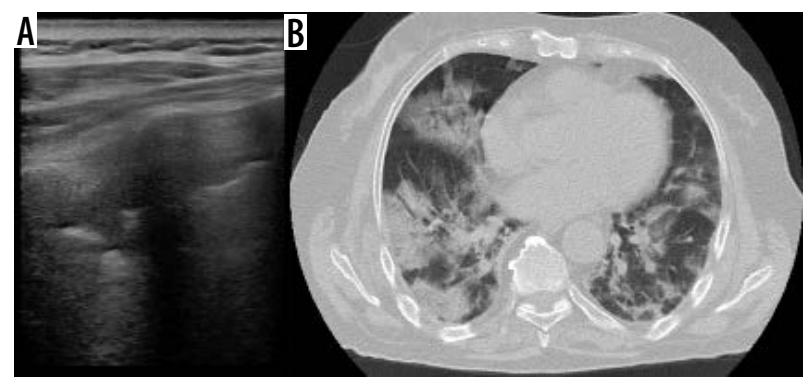

Figure 3. A) Lung ultrasound with linear probe shows subpleural consolidation. B) Chest computed tomography axial image shows bilateral and prevalent peripheral ground-glass opacities, "crazy-paving" pattern and consolidated areas in the left lower lobe

Table 1. Ultrasound findings and results $(N=11)$

\begin{tabular}{|l|c|c|}
\hline Appearance of the lesions & $n / N$ & $\%$ \\
\hline Thickened pleural line & $2 / 11$ & $18 \%$ \\
\hline A-lines & $1 / 11$ & $9 \%$ \\
\hline B-lines in various patterns & $10 / 11$ & $91 \%$ \\
\hline Consolidation & $5 / 11$ & $45 \%$ \\
\hline Pleural effusion & $1 / 11$ & $9 \%$ \\
\hline
\end{tabular}

Specific lung CT findings were observed such as air bronchogram sign (Figures 5 and 6 ) in sixteen patients (76\%), "crazy paving" pattern (Figure 6) in twelve patients (57\%), perilesional vascular thickening in ten patients (47\%), subpleural lines in eight patients (38\%), architectural distortion in four patients (19\%), fibrous stripes in four cases (19\%) and nodules in two cases (9\%). Among extrapulmonary CT features, enlarged mediastinal lymph 
Table 2. Chest $X$-ray findings and results $(N=16)$

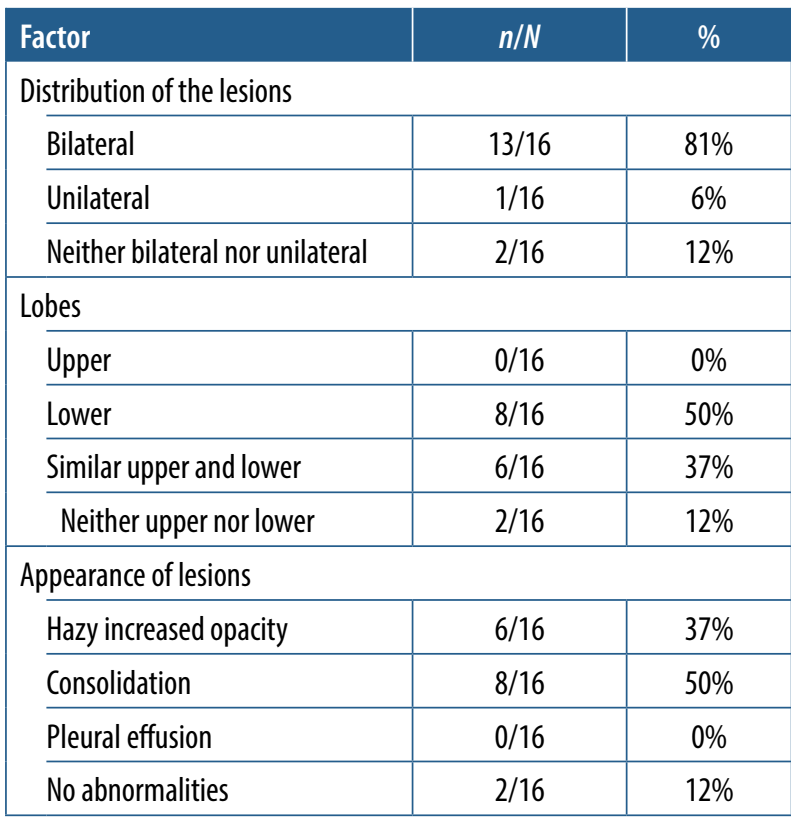

nodes were detected in twelve patients (57\%) and pleural effusion in two patients (9\%). Detailed CT findings are reported in Table 3.

\section{Literature review}

An updated literature review of imaging manifestations of COVID-19 pneumonia including CXR, ultrasound, and CT scans was performed on PubMed by two researchers independently. The search method included the terms "coronavirus", "SARS-CoV-2" and "COVID-19", and aimed to identify retrospective and prospective studies published up to 25th April 2020. We limited our search to English-language studies conducted on human subjects with more than 10 patients in which COVID-19 infection was investigated and we excluded studies focused on pediatric populations.
From the literature search, we found 30 articles $[2,3$, 7-32,34-36] that included a total of 4243 patients, with a mean age of 49.63 years old, male: 2245 and female: 1998. Chest CT abnormalities were reported in all studies whereas only three studies $[2,18,29]$ included CXR findings; finally, lung US abnormalities such as various B-line patterns, subpleural consolidation and thickened pleural line were investigated in one original studies and discussed in two letters to the editor $[2,32,33]$.

\section{Discussion}

As reported in the literature review, to date, there are still few studies with a large population available reporting detailed analysis regarding CXR manifestations. Chen et al. [18] reported bilateral pneumonia as the most common result on CXR, while in the $\mathrm{Ng}$ et al. study [29], only five patients underwent CXR and of these, three had parenchymal consolidations, two showed no alterations, and none had pleural effusion. The CXR results of the included studies are displayed in Table 4.

On the other hand, chest CT abnormalities were largely investigated in recent published works and the most common reported abnormalities associated with COVID-19 pneumonia were isolated GGO, followed by consolidations and GGO in combination with consolidative opacities; the predominant distribution was bilateral, peripheral, subpleural and of the lower lobes. Other CT signs showed heterogeneous results; in particular, the air bronchogram, the crazy-paving pattern and the interstitial thickening (i.e. reticulation pattern) had a detection rate which ranged from $8 \%$ to $80 \%$, from $17.5 \%$ to $81.8 \%$, and, from $8.4 \%$ to $56.5 \%$, respectively. Moreover, the reversed halo sign was described in only three studies: Bernheim et al. found it in 2\% [12], Li et al. in 3.9\% [14], Bai et al. in 5\% [22]. According to the revised studies, lymphadenopathy and pleural effusion were rarely observed.

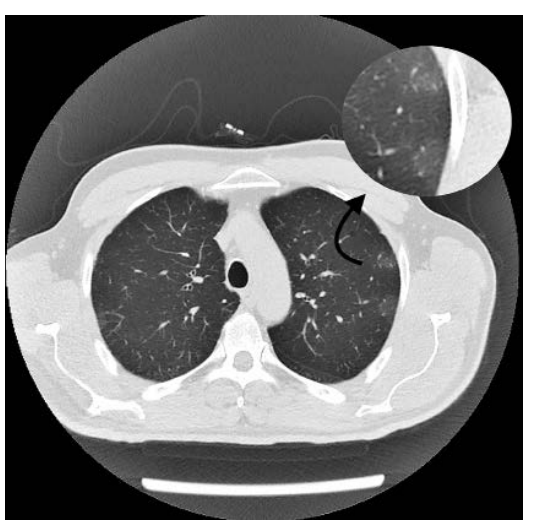

Figure 4. Chest computed tomography axial image shows patchy bilateral and peripheral ground-glass opacities

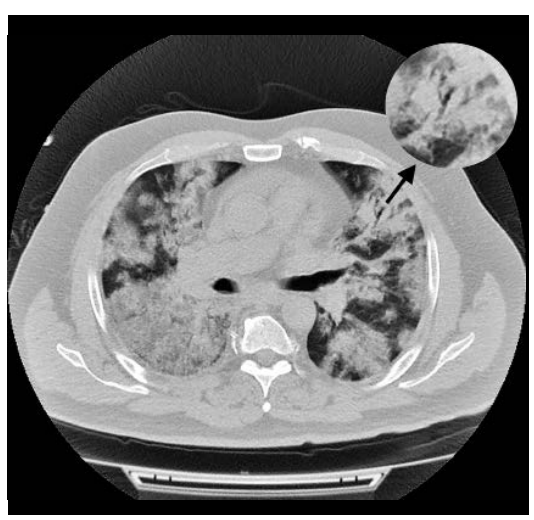

Figure 5. Chest computed tomography axial image shows bilateral and diffuse ground-glass opacities and more consolidated areas with air bronchogram sign

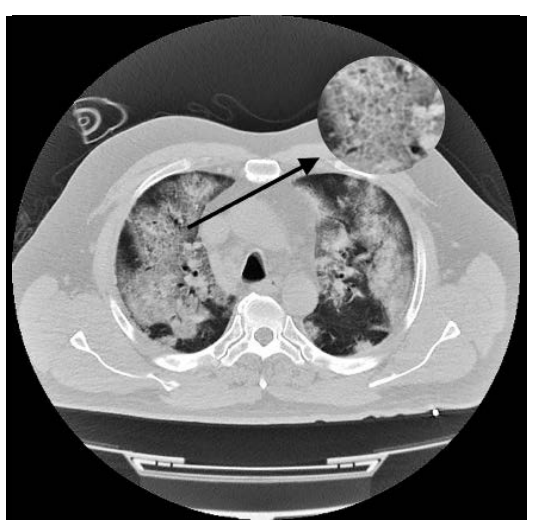

Figure 6. Chest computed tomography axial image shows bilateral and diffuse ground-glass opacities with superimposed interlobular septal thickening and intralobular septal thickening ("crazy paving" pattern) and more consolidated areas with air bronchogram sign 
Interestingly, recent evidence focused on the reliability of disease staging using CT scores [34,35], identifying a correlation between the signs, symptoms, and the stage of the disease. Liu et. al. [34] reported the initial and follow-up characteristics of CT in COVID-19 patients by classifying them based on severity, in patients with mild, common, severe, and critical type. Atelectasis and pleural effusion findings were rarely observed and were found only in critically ill patients, suggesting a worse prognosis when these signs occurred; in the follow-up, CT scans, mostly in patients who had recovered from the disease, GGO, and consolidation were resolved, while the interlobular septum and bronchial wall thickening, band opacities and scattered patchy consolidation were still visible in a minority of patients.

Ding et al. [35] classified the disease into six stages according to the time of the initial symptoms; this study showed no abnormalities at the initial presentation (symptoms of $0-4$ days) in $21.2 \%$ of performed chest CT scans while variable lesions were observed in the progressive phase (5-9 days). In later stages, the presence of crazy paving pattern, consolidation, and linear opacities increased significantly, reflecting the pathological changes with the development of interstitial edema and alveolar exudation. Furthermore, they analyzed the adherence of semiquantitative CT score to the severity of the different stages, showing that the total CT scores of the bilateral lungs were lower in the first stage compared to the other stages, but there was no significant difference between the other stages, suggesting the permanence of disease within ten days after the onset of the initial symptoms.

Regarding our case series, it is interesting to note that, unlike the data reported in the literature relating to chest CT abnormalities, the most frequently detected CT lung findings were GGO with concomitant consolidative opacities $(76 \%)$, rather than isolated GGO, visible only in $24 \%$ of cases. Instevisiblead, according to the revised studies, also in our case series, the predominant distribution was bilateral and peripheral with lower zone involvement (100\%); however, the high central distribution frequency (76\%) should be considered. Similarly, we highlighted a high frequency of presence of air bronchogram sign (76\%) and "crazy paving" pattern (57\%). Regarding the presence of perilesional vascular thickening, we detected this sign in $47 \%$ of cases, which represents an incidence lower than that reported by of Li and Xia (82.4\%) [14] and Zhao et al. (71.3\%) [10] and similar to that observed in the study of Zhou et al. (45.2\%) [11]; this sign is thought to be caused by hyperemia induced by an acute inflammatory response [2]. Regarding the extrapulmonary manifestations, it is interesting to note that in $57 \%$ of cases we detected mediastinal enlarged lymph node, an uncommon finding according to literature data. According to the revised studies, pleural effusion was rarely observed (9\%). Therefore, the set of our findings suggests a higher incidence of more severe and critical disease cases in our case series, as also confirmed by the high mortality
Table 3. Computed tomography chest findings and results $(N=21)$

\begin{tabular}{|c|c|c|}
\hline Factor & $n / N$ & $\%$ \\
\hline \multicolumn{3}{|l|}{ Distribution of the lesions } \\
\hline Peripheral & $21 / 21$ & 100 \\
\hline Central & $16 / 21$ & 76 \\
\hline Peripheral and central & $16 / 21$ & 76 \\
\hline Neither peripheral nor central & - & - \\
\hline \multicolumn{3}{|l|}{ Lobes } \\
\hline Right upper lobe & $18 / 21$ & 85 \\
\hline Right middle lobe & $18 / 21$ & 85 \\
\hline Right lower lobe & $21 / 21$ & 100 \\
\hline Left upper lobe & $20 / 21$ & 95 \\
\hline Left lower lobe & $21 / 21$ & 100 \\
\hline
\end{tabular}

\begin{tabular}{l|c|c|}
\hline No. of lobes \\
\hline 1 & - & - \\
\hline 2 & $1 / 21$ & 4 \\
\hline 3 & - & - \\
\hline 4 & $4 / 21$ & 19 \\
\hline 5 & $16 / 21$ & 76 \\
\hline
\end{tabular}

\begin{tabular}{|c|c|c|}
\hline \multicolumn{3}{|l|}{ Appearance of the lesions } \\
\hline Ground-glass opacity & $21 / 21$ & 100 \\
\hline Consolidation & $14 / 21$ & 66 \\
\hline $\begin{array}{l}\text { Ground-glass opacity with } \\
\text { consolidation }\end{array}$ & $16 / 21$ & 76 \\
\hline No abnormalities & - & - \\
\hline
\end{tabular}

\begin{tabular}{|c|c|c|}
\hline \multicolumn{3}{|l|}{ Specific signs } \\
\hline "Crazy-paving" pattern & $12 / 21$ & 57 \\
\hline Air bronchogram sign & $16 / 21$ & 76 \\
\hline Architectural distortion & $4 / 21$ & 19 \\
\hline Fibrous stripes & $4 / 21$ & 19 \\
\hline Subpleural lines & $8 / 21$ & 38 \\
\hline Vascular thickening & $10 / 21$ & 47 \\
\hline Nodules & $2 / 21$ & 9 \\
\hline
\end{tabular}

Extrapulmonary manifestations

\begin{tabular}{|c|c|c|}
\hline Mediastinal enlarged lymph node & $12 / 21$ & 57 \\
\hline Pleural effusion & $2 / 21$ & 9 \\
\hline \multicolumn{3}{|c|}{ CO-RADS* } \\
\hline CO-RADS 1 & $0 / 21$ & 0 \\
\hline CO-RADS 2 & $0 / 21$ & 0 \\
\hline CO-RADS 3 & $2 / 21$ & 9 \\
\hline CO-RADS 4 & $5 / 21$ & 23 \\
\hline CO-RADS 5 & $14 / 21$ & 66 \\
\hline CO-RADS 6 & $0 / 21$ & 0 \\
\hline
\end{tabular}

*CO-RADS - level of suspicion COVID-19 infection 
Table 4. Literature review of computed tomography imaging manifestations of COVID-19 pneumonia

\begin{tabular}{|c|c|c|c|c|c|c|c|c|}
\hline \multirow{2}{*}{$\begin{array}{l}\text { First author, } \\
\text { publication data } \\
\text { [reference No.] }\end{array}$} & \multicolumn{3}{|c|}{ Patient characteristics } & \multicolumn{5}{|c|}{ CT findings } \\
\hline & $N$ & $\begin{array}{c}\text { Age } \\
\text { (mean) }\end{array}$ & Sex & $\begin{array}{l}\text { Time between onset } \\
\text { and } 7^{\text {st }}\end{array}$ & GGO & $\begin{array}{l}\text { Consoli- } \\
\text { dation }\end{array}$ & Distribution and/or location & Other findings \\
\hline $\begin{array}{l}\text { Huang, } \\
24 \text { January } 2020[7]\end{array}$ & 41 & 49 & $\begin{array}{l}\mathrm{F}: 11 \\
\mathrm{M}: 30\end{array}$ & 8 & Typically present & $\begin{array}{l}\text { Typically } \\
\text { present }\end{array}$ & Bilateral: $40(98 \%)$ & - \\
\hline $\begin{array}{l}\text { Chen, } \\
29 \text { January } 2020 \text { [18] }\end{array}$ & 99 & 55.5 & $\begin{array}{l}\text { F: } 32, \\
M: 67\end{array}$ & N.R. & $14(14 \%)$ & $99(100 \%)$ & $\begin{array}{l}\text { Bilateral: } 74(75 \%) \\
\text { Unilateral: } 25(25 \%)\end{array}$ & - \\
\hline $\begin{array}{l}\text { Chung, } \\
3 \text { February } 2020 \text { [25] }\end{array}$ & 21 & 51 & $\begin{array}{l}\text { F: } 8 \\
M: 13\end{array}$ & N.R. & $18(86 \%)$ & $6(29 \%)$ & $\begin{array}{c}\text { Bilateral: } 16 \text { (76\%) } \\
\text { Unilateral: } 2 \text { (24\%) } \\
\text { Peripheral distribution: } 7 \text { (33\%) }\end{array}$ & $\begin{array}{l}\text { Crazy paving: } 4 \text { (19\%) } \\
\text { Fibrotic streaks or linear opacities: } 3(14 \%)\end{array}$ \\
\hline $\begin{array}{l}\text { Song, } \\
6 \text { February } 2020[26]\end{array}$ & 51 & 49 & $\begin{array}{l}\mathrm{F}: 26 \\
\mathrm{M}: 25\end{array}$ & $\begin{array}{l}\text { median } 4 \text { days } \\
\text { (range } 1 \text { - 14) }\end{array}$ & $\begin{array}{l}\text { Pure GG0: } 39(77 \%) \\
\text { GG0 with } \\
\text { consolidation: } \\
30(59 \%)\end{array}$ & $28(55 \%)$ & $\begin{array}{c}\text { Bilateral: } 44(86 \%) \\
\text { Lower lobes: } 46 \text { (90\%) } \\
\text { Peripheral: } 44(86 \%)\end{array}$ & $\begin{array}{c}\text { Crazy paving: } 38(75 \%) \\
\text { Interstitial thickening or reticulation: } 11(22 \%) \\
\text { Air broncograms: } 41(80 \%) \\
\text { Lymphadenopathy: } 3(6 \%) \\
\text { Pleural effusion: } 4(8 \%)\end{array}$ \\
\hline $\begin{array}{l}\text { Pan, } \\
6 \text { February } 2020 \text { [27] }\end{array}$ & 63 & 44.9 & $\begin{array}{l}\mathrm{F}: 30 \\
\mathrm{M}: 33\end{array}$ & N.R. & $54(85.7 \%)$ & $\begin{array}{c}12 \\
(19.0 \%)\end{array}$ & Number of affected lobes: 3.3 & $\begin{array}{l}\text { Interstitial thickening or reticulation: } \\
\qquad 11(17.5 \%)\end{array}$ \\
\hline $\begin{array}{l}\text { Wang, } \\
7 \text { February } 2020[28]\end{array}$ & 138 & 56 & $\begin{array}{l}\text { F: } 63 \\
\text { M: } 75\end{array}$ & N.R. & $138(100 \%)$ & - & Bilateral: $138(100 \%)$ & - \\
\hline $\begin{array}{l}\mathrm{Ng}, \\
13 \text { February } 2020[29]\end{array}$ & 21 & 56 & $\begin{array}{l}\text { F: } 8 \\
M: 13\end{array}$ & 3 & $18(86 \%)$ & $13(62 \%)$ & $\begin{array}{c}\text { Peripheral: } 18 \text { (86\%) } \\
\text { Perihilar: } 1(5 \%) \\
\text { Upper zone: } 3(14 \%) \\
\text { Lower zone: } 8 \text { (38\%) } \\
\text { Similar upper and lower zone } \\
\text { involvement: } 8 \text { (38\%) }\end{array}$ & - \\
\hline $\begin{array}{l}\text { Pan, } \\
13 \text { February } 2020 \text { [30] }\end{array}$ & 21 & 40 & $\begin{array}{l}\mathrm{F}: 15 \\
\mathrm{M}: 6\end{array}$ & 9-13 days & $15(71 \%)$ & $19(91 \%)$ & $\begin{array}{c}\text { Single lobe: } 3(14 \%) \\
\text { Bilateral multilobe: } 18(86 \%) \\
\text { Peripheral: } 13(62 \%) \\
\text { Random: } 7(33 \%) \\
\text { Diffuse: } 1(4.8 \%)\end{array}$ & Crazy paving: 4 (19\%) \\
\hline $\begin{array}{l}\text { Han, } \\
15 \text { February } 2020 \text { [31] }\end{array}$ & 108 & 45 & $\begin{array}{l}\mathrm{F}: 70 \\
\mathrm{M}: 38\end{array}$ & $\begin{array}{c}1-3 \text { days } \\
\text { (median, } 1 \text { day })\end{array}$ & $\begin{array}{l}65(60 \%) \\
\text { GG0 with } \\
\text { consolidation: } \\
44(41 \%)\end{array}$ & $6(6 \%)$ & $\begin{array}{c}\text { Peripheral: } 97 \text { (90\%) } \\
\quad \text { Central: } 2 \text { (2) } \\
\text { Peripheral and central: } 9(8 \%)\end{array}$ & $\begin{array}{l}\text { Crazy paving: } 43(40 \%) \\
\text { Air broncograms: } 52(48 \%)\end{array}$ \\
\hline $\begin{array}{l}\text { Fang, } \\
19 \text { February } 2020[8]\end{array}$ & 51 & 45 & $\begin{array}{l}\mathrm{F}: 22, \\
\mathrm{M}: 29\end{array}$ & N.R. & $36(72 \%)^{*}$ & N.R. & $\begin{array}{l}\text { Peripherical: } 36(72 \%) \\
\text { Lower lobes: } 36(72 \%)\end{array}$ & $\begin{array}{l}{ }^{*} 36(72 \%) \text { typical CT manifestations } \\
\text { (e.g. peripheral, subpleural ground glass } \\
\text { opacities, often in the lower lobes); } \\
14(28 \%) \text { atypical CT manifestations }\end{array}$ \\
\hline $\begin{array}{l}\text { Xu, } \\
19 \text { February } 2020[9]\end{array}$ & 90 & 50 & $\begin{array}{l}\mathrm{F}: 51 \\
\mathrm{M}: 39\end{array}$ & N.R. & $65(72 \%)$ & $12(13 \%)$ & $\begin{array}{c}\text { Periphery: } 46(51 \%) \\
\text { Bilateral: } 53(59 \%) \\
\text { Upper lobes: } 40(44 \%) \\
\text { Lower lobes: } 47(52 \%)\end{array}$ & $\begin{array}{c}\text { Crazy paving: } 11 \text { (12\%) } \\
\text { Interstitial thickening or reticulation: } 33(37 \%) \\
\text { Air broncograms: } 7(8 \%) \\
\text { Fibrotic streaks or linear opacities: } 55 \text { (61\%) } \\
\text { Lymphadenopathy: } 1(1 \%) \\
\text { Pleural effusion: } 4 \text { (4\%) } \\
\text { Pleural retraction sign/thickening:50 (56\%) }\end{array}$ \\
\hline $\begin{array}{l}\text { Zhao, } \\
19 \text { February } 2020[10]\end{array}$ & 101 & 44.44 & $\begin{array}{l}\text { F: } 45 \\
\text { M: } 56\end{array}$ & N.R. & $87(86.1 \%)$ & $\begin{array}{c}44 \\
(43.6 \%)\end{array}$ & $\begin{array}{c}\text { Unilateral: } 10(9.9 \%) \\
\text { Bilateral: } 83(82.2 \%) \\
\text { Peripheral: } 88(87.1 \%) \\
\text { Central: } 1(1.0 \%) \\
\text { Lower lobes: } 55(54.5 \%) \\
\text { Upper lobes: } 6(5.9 \%)\end{array}$ & $\begin{array}{c}\text { Interstitial thickening or reticulation: } 49 \text { (48.5\%) } \\
\text { Vascular enlargemen: } 72(71.3 \%) \\
\text { Lymphadenopathy: } 1(1.0 \%) \\
\text { Pleural effusion: } 14(13.9 \%)\end{array}$ \\
\hline $\begin{array}{l}\text { Zhou, } \\
19 \text { February } 2020 \text { [11] }\end{array}$ & 62 & 52.8 & $\begin{array}{l}\mathrm{F}: 23 \\
\mathrm{M}: 39\end{array}$ & $\begin{array}{l}10 \text { patients: } \\
1-7 \text { days (mean, } \\
2.2 \pm 1.8 \text { days); } \\
52 \text { patients: } \\
1-14 \text { days (mean, } \\
6.6 \pm 4.0 \text { days) }\end{array}$ & $25(40.3 \%)$ & $\begin{array}{c}21 \\
(33.9 \%)\end{array}$ & $\begin{array}{c}\text { Single lesion: } 10(16.1 \%) \\
\text { Multiple lesion: } 52(83.9 \%) \\
\text { Peripheral: } 48(77.4 \%) \\
\text { Peripheral and central: } 14(22.6 \%)\end{array}$ & $\begin{array}{c}\text { Crazy paving: } 39 \text { (62.9\%) } \\
\text { Air broncograms: } 45(72.6 \%) \\
\text { Vascular enlargement: } 28(45.2 \%) \\
\text { Vacuolar sign: } 34 \text { (54.8\%) } \\
\text { Fibrotic streaks or linear opacities: } 35(56.5 \%) \\
\text { Pleural effusion: } 6 \text { (9.7\%) } \\
\text { Pleural retraction sign/thickening: } 35(56.5 \%)\end{array}$ \\
\hline
\end{tabular}


Table 4. Cont

\begin{tabular}{|c|c|c|c|c|c|c|c|c|}
\hline \multirow{2}{*}{$\begin{array}{l}\text { First author, } \\
\text { publication data } \\
\text { [reference No.] }\end{array}$} & \multicolumn{3}{|c|}{ Patient characteristics } & \multicolumn{5}{|c|}{ CT findings } \\
\hline & $N$ & $\begin{array}{c}\text { Age } \\
\text { (mean) }\end{array}$ & Sex & $\begin{array}{c}\text { Time between onset } \\
\text { and } 1^{\text {ts }}\end{array}$ & GGO & $\begin{array}{l}\text { Consoli- } \\
\text { dation }\end{array}$ & Distribution and/or location & Other findings \\
\hline $\begin{array}{l}\text { Bernheim, } \\
20 \text { February } 2020 \text { [12] }\end{array}$ & 121 & 45.3 & $\begin{array}{l}F: 60 \\
M: 61\end{array}$ & $\begin{array}{l}36 \text { patients: } 0-2 \text { days; } \\
33 \text { patients: } 3-5 \text { days; } \\
25 \text { patients: } \\
6-12 \text { days; } \\
27 \text { patients: unknown }\end{array}$ & $92(76 \%)$ & $\begin{array}{c}53 \\
(43.8 \%)\end{array}$ & $\begin{array}{c}\text { Bilateral: } 73(60 \%) \\
\text { Right lower lobe: } 79(65 \%) \\
\text { Left lower lobe: } 76(63 \%) \\
\text { Peripheral: } 63(52 \%)\end{array}$ & $\begin{array}{c}\text { Crazy paving: } 6 \text { (5\%) } \\
\text { "Reversed halo" sign: } 2 \text { (2\%) } \\
\text { Fibrotic streaks or linear opacities: } 9 \text { (7\%) } \\
\text { Pleural effusion: } 1 \text { (1\%) }\end{array}$ \\
\hline $\begin{array}{l}\text { Xu, } \\
21 \text { February } 2020 \text { [13] }\end{array}$ & 50 & 43.9 & $\begin{array}{l}\mathrm{F}: 21 \\
\mathrm{M}: 29\end{array}$ & N.R. & $21(75.0 \%)$ & $\begin{array}{c}6 \\
(21.4 \%)\end{array}$ & $\begin{array}{c}\text { Peripheral: } 27 \text { (96.4\%) } \\
\text { Central: } 14(50.0 \%) \\
\text { Peripheral involving central: } \\
12 \text { (42.9\%) } \\
\text { Symmetrical: } 15(53.6 \%)\end{array}$ & $\begin{array}{c}\text { Thickened intralobular septa: } 21(75.0 \%) \\
\text { Thickened interlobular septa: } 20(71.4 \%) \\
\text { Air broncograms: } 15(53.6 \%) \\
\text { Lymphadenopathy: } 1(3.6 \%) \\
\text { Pleural effusion: } 2(7.1 \%)\end{array}$ \\
\hline $\begin{array}{l}\text { Li, } \\
21 \text { February } 2020 \text { [14] }\end{array}$ & 51 & 58 & $\begin{array}{l}\mathrm{F}: 24 \\
\mathrm{M}: 29\end{array}$ & N.R. & $46(90.20 \%)$ & $\begin{array}{c}31 \\
(60.78 \%)\end{array}$ & \begin{tabular}{|c|} 
Single lobe: $3(5.9 \%)$ \\
Bilateral multilobe: $32(94.1 \%)$ \\
Peripheral and subpleural: $49(96.1 \%)$
\end{tabular} & $\begin{array}{c}\text { Crazy paving: } 36(70.6 \%) \\
\text { Air broncograms: } 35(68.6 \%) \\
\text { "Reversed halo" sign: } 2(3.9 \%) \\
\text { Vascular enlargement: } 42(82.4 \%) \\
\text { Pleural effusion: } 1(2 \%)\end{array}$ \\
\hline $\begin{array}{l}\text { Wu, } \\
21 \text { February } 2020 \text { [15] }\end{array}$ & 80 & 44 & $\begin{array}{l}\mathrm{F}: 38 \\
\mathrm{M}: 42\end{array}$ & $7 \pm 4$ & $73(91 \%)$ & $\begin{array}{c}50 \\
(63 \%)\end{array}$ & $\begin{array}{l}\text { Subpleural: } 42(53 \%) \\
\quad \text { Diffuse: } 7 \text { (9\%) } \\
\text { Peribronchial: } 3(4 \%) \\
\text { Mixed: } 24(30 \%)\end{array}$ & $\begin{array}{l}\text { Crazy paving: } 23(29 \%) \\
\text { Interstitial thickening or reticulation: } 47(59 \%) \\
\text { Spider web sign: } 20(25 \%) \\
\text { Lymphadenopathy: } 3(4 \%) \\
\text { Pleural effusion: } 5(6 \%)\end{array}$ \\
\hline $\begin{array}{l}\text { Shi, } \\
24 \text { February } 2020 \text { [16] }\end{array}$ & 81 & 49.5 & $\begin{array}{l}\text { F: } 39 \\
\text { M: } 42\end{array}$ & N.R. & $53(65.4 \%)$ & $\begin{array}{c}14 \\
(17.3 \%)\end{array}$ & $\begin{array}{c}\text { Unilateral: } 17(21 \%) \\
\text { bilateral: } 64(79 \%) \\
\text { central: } 10(12.4 \%) \\
\text { Peripheral: } 44(54.3 \%) \\
\text { Both central and peripheral: } \\
\quad 27(33.3 \%)\end{array}$ & $\begin{array}{c}\text { Crazy paving: } 8 \text { (9.9\%) } \\
\text { Interstitial thickening or reticulation: } 3 \text { (3.7\%) } \\
\text { Air broncograms: } 38(46.9 \%) \\
\text { Lymphadenopathy: } 5(6.2 \%) \\
\text { Pleural effusion: } 4 \text { (4.9\%) } \\
\text { Pleural retraction sign/thickening: } 26 \text { (32.1\%) }\end{array}$ \\
\hline $\begin{array}{l}\text { Yang, } \\
\text { 26 February } 2020 \text { [17] }\end{array}$ & 149 & 45.11 & $\begin{array}{l}\mathrm{F}: 68 \\
\mathrm{M}: 81\end{array}$ & $\begin{array}{l}\text { median } 7.61 \text { days } \\
\quad \text { (range } 0-7 \text { ) }\end{array}$ & \begin{tabular}{|c|} 
Rported as $\mathrm{GGO}$ \\
on $287(12.1 \%)$ \\
segments and mixed \\
$\mathrm{GG0}$ on $637(26.8 \%)$ \\
segments
\end{tabular} & $\begin{array}{l}\text { Reported } \\
\text { as present } \\
\text { on } 170 \\
(7.2 \%) \\
\text { segments }\end{array}$ & $\begin{array}{l}\text { Peripheral: } 35.9 \% \\
\text { Central: } 2.15 \% \\
\text { Both: } 8.12 \%\end{array}$ & $\begin{array}{l}\text { Interstitial thickening or reticulation: } 79 \text { (53\%) } \\
\text { Air broncograms: } 81 \text { (54\%) } \\
\text { Fibrotic streaks or linear opacities:31 (21\%) } \\
\text { Lymphadenopathy: } 7 \text { (5\%) } \\
\text { Pleural effusion: } 10(7 \%)\end{array}$ \\
\hline $\begin{array}{l}\text { Ai, } \\
26 \text { February } 2020 \text { [19] }\end{array}$ & 1014 & 51 & $\begin{array}{l}\text { F: } 547, \\
\text { M: } 467\end{array}$ & N.R. & $409(40 \%)$ & $\begin{array}{c}447 \\
(44 \%)\end{array}$ & - & Interstitial thickening or reticulation: 8 (8\%) \\
\hline $\begin{array}{l}\text { Li, } \\
29 \text { February } 2020 \text { [20] }\end{array}$ & 83 & 45.5 & $\begin{array}{l}\text { F: } 39 \\
\text { M: } 44\end{array}$ & $\begin{array}{c}58 \text { patients: median } \\
6 \text { days (range: } 3-8.5 \\
\text { days); } 25 \text { patients: } \\
\text { median } 8 \text { days } \\
\text { (range: } 6-12 \text { days) }\end{array}$ & $81(97.6 \%)$ & $\begin{array}{c}53 \\
(63.9 \%)\end{array}$ & $\begin{array}{c}\text { Bilateral: } 79(95.2 \%) \\
\text { Lower lobe: } 80(96.4 \%) \\
\text { Right lower lobe: } 78(94 \%) \\
\text { Left lower lobe: } 80(96.4 \%)\end{array}$ & $\begin{array}{l}\text { Crazy paving: } 30 \text { (36.1\%) } \\
\text { Interstitial thickening or reticulation: } \\
52 \text { (62.7\%) } \\
\text { Fibrotic streaks or linear opacities: } 54 \text { (65.1\%) } \\
\text { Spider web sign: } 21 \text { (25.3\%) } \\
\text { Pleural effusion: } 7(8.4 \%) \\
\text { Pleural retraction sign/thickening: } 7(8.4 \%)\end{array}$ \\
\hline $\begin{array}{l}\text { Xiong, } \\
3 \text { March } 2020 \text { [21] }\end{array}$ & 42 & 49.5 & $\begin{array}{l}\text { F: } 17 \\
\text { M: } 25\end{array}$ & $\begin{array}{c}\text { mean } 4.5 \text { days (range } \\
1-11 \text { days) }\end{array}$ & $\begin{array}{l}n \text { of lobes with } \\
\text { opacification: } \\
158 / 210(75 \%)\end{array}$ & $\begin{array}{c}23 \\
(55 \%)\end{array}$ & $\begin{array}{c}\text { Single lobe: } 10(24 \%) \\
\text { Bilateral multilobe: } 32(76 \%) \\
\text { Central: } 5(12 \%) \\
\text { Peripheral: } 12(29 \%) \\
\text { Both central and peripheral: } 25(59 \%) \\
\end{array}$ & $\begin{array}{l}\text { Interstitial thickening or reticulation: } 17 \text { (41\%) } \\
\text { Air broncograms: } 14 \text { (33\%) } \\
\text { Fibrotic streaks or linear opacities: } 15(36 \%) \\
\text { Lymphadenopathy: } 12(29 \%) \\
\text { Pleural effusion: } 5(12 \%)\end{array}$ \\
\hline $\begin{array}{l}\text { Wang, } \\
4 \text { March } 2020 \text { [36] }\end{array}$ & 114 & 53 & $\begin{array}{l}\text { F: } 56 \\
\text { M: } 58\end{array}$ & N.R. & \begin{tabular}{|c|} 
Ground-glass \\
opacity: $27.3 \%$ \\
Ground-glass opacity \\
and consolidation: \\
$45.4 \%$
\end{tabular} & $27.3 \%$ & $\begin{array}{c}\text { Peripheral zone: } 43.6 \% \\
\text { Central zone: } 0 \% \\
\text { Both: } 56.4 \% \\
\text { Single lobe of one lung: } 9.1 \% \\
\text { Multiple lobes of one lung: } 5.5 \% \\
\text { Multiple lobes of both lungs: } 72.7 \% \\
\text { Bilateral lower lungs: } 3.6 \% \\
\text { Bilateral middle and lower lungs: } 9.1 \%\end{array}$ & Pleural effusion: $0.9 \%$ \\
\hline
\end{tabular}


Table 4. Cont.

\begin{tabular}{|c|c|c|c|c|c|c|c|c|}
\hline \multirow{2}{*}{$\begin{array}{l}\text { First author, } \\
\text { publication data } \\
\text { [reference No.] }\end{array}$} & \multicolumn{3}{|c|}{ Patient characteristics } & \multicolumn{5}{|c|}{ CT findings } \\
\hline & $N$ & $\begin{array}{c}\text { Age } \\
\text { (mean) }\end{array}$ & Sex & $\begin{array}{l}\text { Time between onset } \\
\text { and } 7^{\text {st }}\end{array}$ & GGO & $\begin{array}{l}\text { Consoli- } \\
\text { dation }\end{array}$ & Distribution and/or location & Other findings \\
\hline $\begin{array}{l}\text { Guan, } \\
6 \text { March } 2020 \text { [3] }\end{array}$ & 1099 & 47.0 & $\begin{array}{l}\text { F: } 459, \\
\text { M: } 640\end{array}$ & N.R. & $550(56.4 \%)$ & $\begin{array}{c}409 \\
(41.9 \%)\end{array}$ & Bilateral: 505 (51.8\%) & Interstitial thickening or reticulation: 43 (14.7\%) \\
\hline $\begin{array}{l}\text { Liu, } \\
7 \text { March } 2020 \text { [34] }\end{array}$ & 73 & 41.6 & $\begin{array}{l}F: 32 \\
M: 41\end{array}$ & N.R. & \begin{tabular}{|c|} 
Unique ground-glass \\
opacities: $28-100 \%$ \\
Multiple ground- \\
glass opacities: \\
$72-100 \%$
\end{tabular} & $\begin{array}{l}\text { *Severe } \\
\text { type: } 24 \% \\
{ }^{*} \text { Critical } \\
\text { type: } \\
100 \%\end{array}$ & $\begin{array}{l}\text { Unilateral lung involvement: 35\% } \\
\text { Bilateral lung involvement: 50-100\% }\end{array}$ & $\begin{array}{c}\text { Paving stone sign: } 35-100 \% \\
\text { Bronchial wall thickening: } 5-100 \% \\
\text { Pleural effusion: } 0-100 \% \\
\text { Thickening of lung texture: } 50-100 \%\end{array}$ \\
\hline $\begin{array}{l}\text { Bai, } \\
10 \text { March } 2020 \text { [22] }\end{array}$ & 219 & 44.8 & $\begin{array}{l}\text { F: } 100, \\
\text { M: } 119\end{array}$ & 4.9 & $200(91 \%)$ & $150(69 \%)$ & $\begin{array}{c}\text { Unilateral: } 41(19 \%) \\
\text { Bilateral: } 165(75 \%) \\
\text { Central: } 3(1 \%) \\
\text { Peripheral: } 176(80 \%) \\
\text { Central + peripheral: } 31(14 \%)\end{array}$ & $\begin{array}{c}\text { Crazy paving: } 11(5 \%) \\
\text { Interstitial thickening or reticulation:123 (56\%) } \\
\text { Air broncograms: } 30 \text { (14\%) } \\
\text { "Reversed halo" sign: } 11(5 \%) \\
\text { Fibrotic streaks or linear opacities: } 111 \text { (51\%) } \\
\text { Lymphadenopathy: } 6(3 \%) \\
\text { Pleural Effusion: } 9 \text { (4\%) } \\
\text { Pleural retraction sign/thickening: } 32 \text { (15\%) }\end{array}$ \\
\hline $\begin{array}{l}\text { Zhao, } \\
13 \text { March } 2020 \text { [23] }\end{array}$ & 19 & 48 & $\begin{array}{l}\mathrm{F}: 8 \\
\mathrm{M}: 11\end{array}$ & 5.0 & $17(89.47 \%)$ & N.R. & $\begin{array}{c}\text { Single lobe: } 4 \text { (21.05\%) } \\
\text { Bilateral: } 15(78.95 \%)\end{array}$ & - \\
\hline $\begin{array}{l}\text { Cheng, } \\
14 \text { March } 2020 \text { [24] }\end{array}$ & 11 & 50.36 & $\begin{array}{l}\mathrm{F}: 3 \\
\mathrm{M}: 8\end{array}$ & N.R. & $\begin{array}{l}\text { GG0 } 11(100 \%) \\
\text { Mixed GG0 } \\
(63.6 \%)\end{array}$ & $6(54.5 \%)$ & $\begin{array}{c}\text { Peripheral: } 11(100 \%) \\
\text { Right lower lobe: } 8 \text { (72.7\%) } \\
\text { Left lower lobe: } 7(63.6 \%)\end{array}$ & $\begin{array}{l}\text { Interstitial thickening or reticulation: } 9(81.8 \%) \\
\text { Air broncograms: } 8(72.7 \%) \\
\text { Fibrotic streaks or linear opacities: } 2(18.2 \%)\end{array}$ \\
\hline $\begin{array}{l}\text { Lomoro, } \\
4 \text { April } 2020[2]\end{array}$ & 42 & 66.3 & $\begin{array}{l}F: 22 \\
M: 36\end{array}$ & N.R. & $15(35.7 \%)$ & $0(0 \%)$ & $\begin{array}{c}\text { Peripheral: } 27(64.3 \%) \\
\text { Central: } 1(2.4 \%) \\
\text { Peripheral and central: } 12(28.6 \%) \\
\text { Neither peripheral or central: } 2 \text { (4.8\%) }\end{array}$ & $\begin{array}{c}\text { Vascular thickening: } 10(23.8 \%) \\
\text { Crazy paving pattern: } 24(57.1 \%) \\
\text { Air bronchogram sign: } 11(26.2 \%) \\
\text { Bronchus deformation: } 12(28.6 \%) \\
\text { Noduls: } 1(2.4 \%) \\
\text { Pleural effusion: } 3(7.1 \%) \\
\text { Fibrous stripes: } 21(50 \%) \\
\text { Subpleural lines: } 15(35.7 \%) \\
\text { Lymph node: } 6(14.3 \%)\end{array}$ \\
\hline $\begin{array}{l}\text { Ding, } \\
8 \text { April } 2020 \text { [35] }\end{array}$ & 112 & 55.8 & $\begin{array}{l}\text { F: 61, } \\
\text { M: } 51\end{array}$ & 8.0 & $76-98.1 \%$ & $25.5-75 \%$ & $\begin{array}{l}\text { Mostly peripheral at all stages with } \\
\text { the highest rate (66.6\%) at stage } 2, \\
\text { and with the development of the } \\
\text { disease the lesions gradually spread } \\
\text { from the periphery to the center } \\
\text { Bilaterally, in multiple lobes, with } \\
\text { the lowest rate }(42.5 \%) \text { at stage } 1 \text { and } \\
\text { the highest rate }(95.6 \%) \text { at stage } 4\end{array}$ & $\begin{array}{l}\text { Air bronchogram, bronchiectasis and pleural } \\
\text { effusion with their maximum frequencies } \\
\text { occurring in stage 2: } 50.0 \% \text {, stage } 6: 45.2 \% \\
\text { and stage } 4: 27.9 \% \\
\text { Pericardial effusion: } 4.4 \% \\
\text { Pneumothorax: } 3.8 \%\end{array}$ \\
\hline
\end{tabular}

GG0 - ground-glass opacity, N.R. - not reported, CT - computed tomography

rate of our case series (6 patients: $26 \%$ ). These data can be explained by patients' access to the hospital at a later stage in the history of the disease.

Limitations of our study were related to the retrospective design, the small sample size, and the lack of follow-up studies; in fact, we only included imaging evaluations performed at the time of hospitalization.

In conclusion, we provided a current and exhaustive overview of multi-modality lung imaging findings observed in patients with COVID-19 pneumonia, and we described the typical US, CXR, and CT features detected at hospital admission, thus helping radiologists to recognize this novel, severe and pandemic infectious disease.

\section{Acknowledgments}

All procedures performed in studies involving human participants were in accordance with the ethical standards of the institutional and/or national research committee and with the 1964 Helsinki Declaration and its later amendments or comparable ethical standards.

Informed consent was obtained from all individual participants included in the study.

\section{Conflict of interest}

The authors report no conflict of interest. 
References

1. Yu M, Xu D, Lan L, et al. Thin-section chest CT Imaging of Coronavirus disease 2019 pneumonia: comparison between patients with mild and severe disease. Radiology 2020; 2. doi: https://doi. org/10.1148/ryct.2020200126.

2. Lomoro P, Verde F, Zerboni F, et al. COVID-19 pneumonia manifestations at the admission on chest ultrasound, radiographs, and CT: single-center study and comprehensive radiologic literature review. Eur J Radiol Open 2020; 7: 100231.

3. Guan WJ, Ni ZY, Hu Y, et al. China medical treatment expert group for Covid-19. Clinical characteristics of coronavirus disease 2019 in China. N Engl J Med 2020; 382: 1708-1720.

4. WHO. Novel Coronavirus (2019-nCoV). Situation report - 7. Available from: https://www.who.int/publications-detail/global-surveillance-for-human-infection-with-novel-Coronavirus-(2019-ncov) (Accessed: 27.02.2020).

5. Kang Z, Li X, Zhou S. Recommendation of low-dose CT in the detection and management of COVID-2019. Eur Radiol 2020; 19: 1-2.

6. Hansell DM, Bankier AA, MacMahon H, et al. Fleischner Society: glossary of terms for thoracic imaging. Radiology 2008; 246: 697 722.

7. Huang C, Wang Y, Li X, et al. Clinical features of patients infected with 2019 novel coronavirus in Wuhan, China. Lancet 2020; 395: 497-506.

8. Fang Y, Zhang H, Xie J, et al. Sensitivity of chest CT for COVID-19: comparison to RT-PCR. Radiology 2020; 19: 200432.

9. Xu X, Yu C, Qu J, et al. Imaging and clinical features of patients with 2019 novel coronavirus SARS-CoV-2. Eur J Nucl Med Mol Imaging 2020; 47: 1275-1280.

10. Zhao W, Zhong Z, Xie X, et al. Relation between chest ct findings and clinical conditions of coronavirus disease (covid-19) pneumonia: a multicenter study. AJR Am J Roentgenol 2020; 214: 1072-1077.

11. Zhou S, Wang Y, Zhu T, et al. CT features of Coronavirus disease 2019 (COVID-19). Pneumonia in 62 patients in Wuhan, China. AJR Am J Roentgenol 2020; 214: 1287-1294.

12. Bernheim A, Mei X, Huang M, et al. Chest CT findings in Coronavirus disease-19 (COVID-19): relationship to duration of infection. Radiology 2020; 20: 200463.

13. Xu YH, Dong JH, An WM, et al. Clinical and computed tomographic imaging features of novel coronavirus pneumonia caused by SARSCoV-2. J Infect 2020; 80: 394-400.

14. Li Y, Xia L. Coronavirus disease 2019 (COVID-19): role of chest CT in diagnosis and management. AJR Am J Roentgenol 2020; 214 : 1280-1286.

15. Wu J, Wu X, Zeng W, et al. Chest CT findings in patients with Coronavirus disease 2019 and its relationship with clinical features. Invest Radiol 2020; 55: 257-261.

16. Shi H, Han X, Jiang N, et al. Radiological findings from 81 patients with COVID-19 pneumonia in Wuhan, China: a descriptive study. Lancet Infect Dis 2020; 20: 425-434.

17. Yang W, Cao Q, Qin L, et al. Clinical characteristics and imaging manifestations of the 2019 novel coronavirus disease (COVID-19): a multi-center study in Wenzhou city, Zhejiang, China. J Infect 2020; 80: 388-393.

18. Chen N, Zhou M, Dong X, et al. Epidemiological and clinical characteristics of 99 cases of 2019 novel coronavirus pneumonia in Wuhan, China: a descriptive study. Lancet 2020; 395: 507-513.
19. Ai T, Yang Z, Hou H, et al. Correlation of chest CT and RT-PCR testing in Coronavirus disease 2019 (COVID-19) in China: a report of 1014 cases. Radiology 2020; 26: 200642.

20. Li K, Wu J, Wu F, et al. The clinical and chest ct features associated with severe and critical COVID-19 pneumonia. Invest Radiol 2020; 55: 327-331.

21. Xiong Y, Sun D, Liu Y, et al. Clinical and high-resolution CT features of the COVID-19 infection: comparison of the initial and follow-up changes. Invest Radiol 2020; 55: 332-339.

22. Bai HX, Hsieh B, Xiong Z, et al. Performance of radiologists in differentiating COVID-19 from viral pneumonia on chest CT. Radiology 2020; 10: 200823.

23. Zhao D, Yao F, Wang L, et al. A comparative study on the clinical features of COVID-19 pneumonia to other pneumonias. Clin Infect Dis 2020; 12: ciaa247.

24. Cheng Z, Lu Y, Cao Q, et al. Clinical features and chest CT manifestations of Coronavirus disease 2019 (COVID-19) in a single-center study in Shanghai, China. AJR Am J Roentgenol 2020; 14: 1-6.

25. Chung M, Bernheim A, Mei X, et al. CT imaging features of 2019 novel Coronavirus (2019-nCoV). Radiology 2020; 295: 202-207.

26. Song F, Shi N, Shan F, et al. Emerging 2019 novel Coronavirus (2019nCoV) pneumonia. Radiology 2020; 295: 210-217.

27. Pan $Y$, Guan $H$, Zhou S, et al. Initial CT findings and temporal changes in patients with the novel coronavirus pneumonia (2019-nCoV): a study of 63 patients in Wuhan, China. Eur Radiol 2020; 30: 3306-3309.

28. Wang D, Hu B, Hu C, et al. Clinical characteristics of 138 hospitalized patients with 2019 novel Coronavirus-Infected pneumonia in Wuhan, China. JAMA 2020; 323: 1061-1069.

29. Ng M-Y, Lee EY, Yang J, et al. Imaging profile of the COVID-19 infection: radiologic findings and literature review. Radiol Cardiothorac Imaging 2020; 2: e200034.

30. Pan F, Ye T, Sun P, et al. Time course of lung changes on chest CT during recovery from 2019 novel Coronavirus (COVID-19) pneumonia. Radiology 2020; 13: 200370.

31. Han R, Huang L, Jiang H, et al. Early clinical and CT manifestations of coronavirus disease 2019 (Covid-19) pneumonia. AJR Am J Roentgenol 2020; 17: 1-6.

32. Poggiali E, Dacrema A, Bastoni D, et al. can lung US help critical care clinicians in the early diagnosis of novel Coronavirus (COVID-19) pneumonia? Radiology 2020; 13: 200847.

33. Peng QY, Wang XT, Zhang LN, et al. Findings of lung ultrasonography of novel corona virus pneumonia during the 2019-2020 epidemic. Intensive Care Med 2020; 46: 849-850.

34. Liu KC, Xu P, Lv WF, et al. CT manifestations of coronavirus disease-2019: a retrospective analysis of 73 cases by disease severity. Eur J Radiol 2020; 126: 108941.

35. Ding X, Xu J, Zhou J, et al. Chest CT findings of COVID-19 pneumonia by duration of symptoms. Eur J Radiol 2020; 127: 109009.

36. Wang K, Kang S, Tian R, et al. Imaging manifestations and diagnostic value of chest CT of coronavirus disease 2019 (COVID-19) in the Xiaogan area. Clin Radiol 2020; 75: 341-347.

37. Bai HX, Hsieh B, Xiong Z, et al. Performance of radiologists in differentiating COVID 19 from viral pneumonia on chest CT. Radiology 2020; 296: E46-E54. 